\title{
Hard clam Meretrix lusoria to Hg-stressed birnavirus susceptibility revealed through stage-structured disease transmission dynamics
}

\author{
Chung-Min Liao*, Ching-Hung Yeh \\ Department of Bioenvironmental Systems Engineering, National Taiwan University, Taipei, Taiwan 10617, ROC
}

Received 25 October 2006; received in revised form 25 December 2006; accepted 26 December 2006

\begin{abstract}
The purpose of this study was to assess the effects of mercury $(\mathrm{Hg})$ on birnavirus infection in the farmed hard clam (Meretrix lusoria) populations. A stage-structured matrix population model was linked with a nonlinear epidemiological dynamics of hostpathogen model to quantify the effects of increased $\mathrm{Hg}$-stressed birnavirus on population dynamics of disease in hard clam populations. Bioenergetics was incorporated into population stage-structured model to enhance life cycle toxicity assessment on constraining reproduction and growth in life stages of hard clams. We delineated three qualitatively distinct scenarios of virus only, $\mathrm{Hg}+$ virus, and virus $+\mathrm{Hg}$. Within a range of disease transmissibility drawn from analysis of $\mathrm{Hg}$-stressed birnavirus in hard clams, different transmissibility led to simulated outbreaks characterized by basic reproductive number $\left(R_{0}\right)$ depicting the allowance population numbers to contain disease spread for all three scenarios. This study suggested that recognizing which of the scenarios best describing a situation in the field could aid in planning disease management and in choosing the most efficient and feasible strategy. The present simple model captured the essential dynamics and its flexible enough to integrate effects occurring at varying temporal scales based on biologically plausible and empirically grounded dynamical models. We were confident that the model could be easily adapted for other aquaculture species and encourage researchers to use the model to diagnose the population-level risk of toxic chemical-stressed pathogen on these species.
\end{abstract}

(C) 2007 Elsevier B.V. All rights reserved.

Keywords: Aquaculture; Hard clam; Matrix population model; Infectious disease dynamics; Bioenergetics; Host-pathogen interaction; Mercury

\section{Introduction}

Increasing evidence both from field observations and experimental studies showed that a strong correlation existed between risk of infection establishment and spread associated with serious economic and ecological problems in aquaculture species (Murray and Peeler, 2005). Chou et al. (1998) demonstrated that an increase in heavy metal stresses such as $\mathrm{Cu}, \mathrm{Cd}, \mathrm{Hg}$, and $\mathrm{Zn}$ had a

\footnotetext{
* Corresponding author. Tel.: +88622363 4512; fax: +88622362 6433.

E-mail address: cmliao@ntu.edu.tw (C.-M. Liao).
}

marked effect on the susceptibility of hard clam (Meretrix lusoria) to a low pathogenic infectious pancreatic necrosis virus (IPNV)-like aquaculture birnavirus infection. Chou et al. (1999) further indicated that an infectious pancreatic necrosis virus (IPNV) with only low pathogenicity could cause high mortality in groupers (Epinephelus sp.) when combined with heavy metal stressors such as $\mathrm{Zn}, \mathrm{Cd}$, and $\mathrm{Cu}$. Heinonen et al. (1999) indicated that trematode parasite infection affected accumulation of xenobiotics in freshwater clam Pisidium amnicum, suggesting that natural stress factors like parasite infections and environmentally relevant abiotic factor should be better understood and applied in ecotoxicological studies. 
Arkoosh et al. (1994, 1998, 2001) and Loge et al. (2005) revealed that pollution-stressed immunodysfunction in juvenile Chinook salmon (Oncorhynchus tshawytscha) might lead to increased susceptibility to infection by a virulent marine pathogen Vibrio anguillarum. Hall et al. (2006a) indicated that the risk of death from infectious disease in harbor porpoises was associated with increasing polychlorinated biphenyls (PCBs) exposure.

Great potential benefits would be gained from any appropriate management able to control the spread of the infectious diseases and eliminate it from the aquaculture species populations. On the other hand, mitigation of environmental stressors that increased the risk of host susceptibility to the spread of emerging disease, however, posed a challenge to the design of an effective control strategy. Analysis of infectious disease ecology and host-pathogen interactions including pathogen transmission and disease manifestations were central to successful control strategies (Anderson and May, 1991). Environmental chemical stresses affected ecological endpoints such as intrinsic rates of increase, carrying capacity, and density dependence of populations involving in density-toxicant interactions (Sibly et al., 2000; Forbes et al., 2001; Hendriks et al., 2005). Here we employed the matrix population model to account for the population dynamics (Caswell, 2001). Disease models based on the matrix population models not only allowed asymptotic analysis to estimate the net reproduction rate of the disease and growth rate of the population, but also provided a flexible framework for modeling epidemiological processes of the disease and population dynamics and infection control program (Liao et al., 2006; Oli et al., 2006).

In the recent years the concept of assimilated energy utilization had been extensively employed to determine the growth of organisms and the productivity of ecosystems and the life cycle toxicity assessment (Jager et al., 2004; Nichols et al., 2004; Tsai and Liao, 2006; Klanjscek et al., 2006; Péry et al., 2006). The basic insight was that exposure to toxicants could be understood as a change in energetic parameters, such as an increase in the maintenance (including detoxification) costs or a decrease of the assimilation of energy from food (Péry et al., 2003; Jager et al., 2004; Klanjscek et al., 2006). Aquaculture species constantly consumed energy in order to maintain life and offset effects of multiple stressors such as daily fluctuations of water temperature, availability of food, and pollutants in the environment. Therefore, assessing the impact of chronically exposure to chemicals by using the energy metabolism as a performance response could be a rigorous physiological and ecological approach to toxicity assessment. Péry et al.
(2006) further argued that bioenergetics-based models provided appropriate kinetics estimates, which made actual kinetics measurements unnecessary.

Hard clam M. lusoria, being cultured in large quantities in intertidal sandflats and ponds, was chosen for study mainly because of its economic importance in Taiwan and heavy metal pollution issues. The production of hard clams was currently nearly 24,000 ton per year (http://www.fagov.tw/chn/index.php). Data obtained from previous published bioaccumulation and acute and chronic toxicity bioassays were reanalyzed to reconstruct concentration-response profiles and to examine the survival and growth performances. These data provided stage-specific schedules of vital rates that are used to parameterize a matrix population model for hard clams. Simulations were carried out to produce population abundance changes over time under different exposure scenarios. Asymptotic population growth rates were estimated from matrix population models along with stage-specific mode of action (MOA) to further provide population-level ecotoxicological endpoints. A deterministic susceptibility-infectious-mortality model linking with a population dynamics of disease model was used to estimate the epidemiologically relevant endpoints such as transmissibility and basic reproductive number.

The objectives of this paper were twofold: (1) to link a stage-structured population growth method with a nonlinear epidemiological dynamics of host-pathogen model to investigate the effects of increased $\mathrm{Hg}$-stressed birnavirus on the population dynamics of disease in hard clam populations and (2) to incorporate a bioenergeticsbased model into the population stage-structured model to enhance the life cycle toxicity assessment of the effects of $\mathrm{Hg}$-stressed birnavirus on reproduction and growth for life stages of hard clams.

\section{Materials and methods}

\subsection{Stage-structured matrix model}

To develop the stage-structured population growth model of hard clam, a four-stage (embryos/larvae to juveniles to sub-adults to adults) matrix model was used to project offspring production through two generations based on the body weight as suggested by Fisheries Administration, Council of Agriculture, ROC (http://www. fagov.tw/chn/index.php), indicating that the duration of each life stage of hard clam was estimated to be $3,5,8$, and 16 months, respectively, yielding a life span of 32 months.

Based on the stage-specific survival and life stage transition rates and fecundity through sub-adults and adults, a four-stage matrix population model (MPM) 


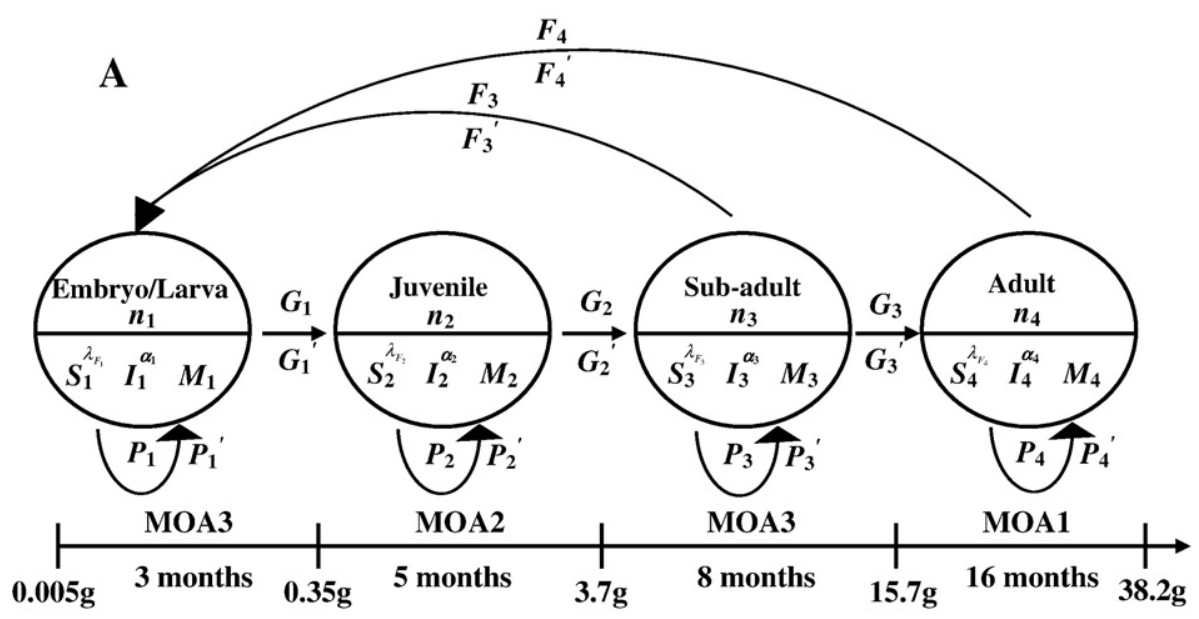

B

Winter

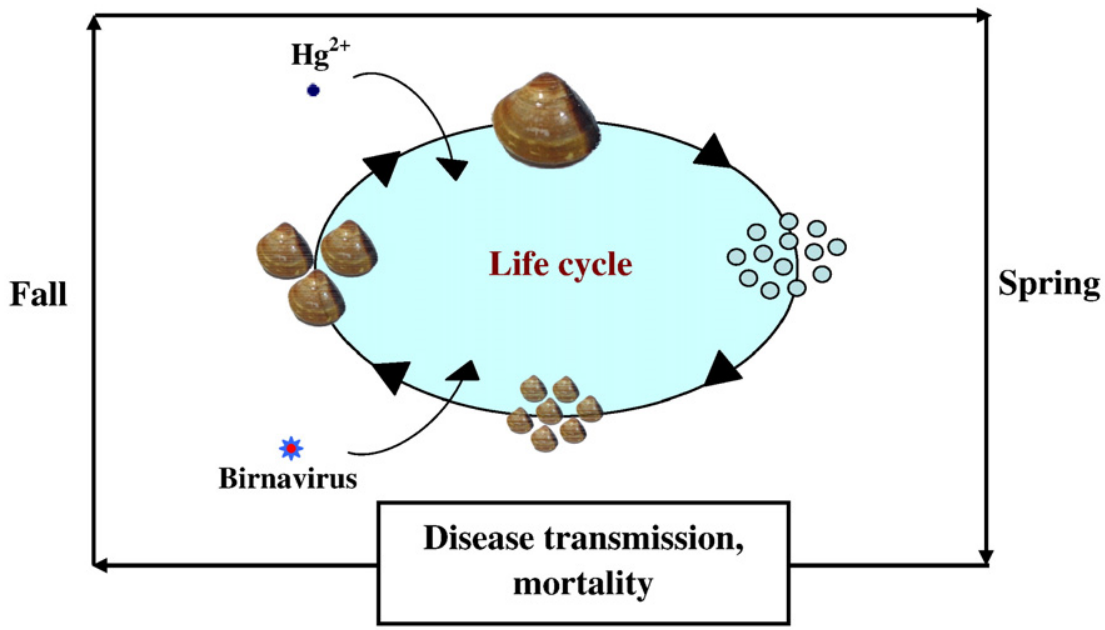

Summer

Fig. 1. Schematic diagrams of the model structure. (A) A four-stage life cycle graph of an individual hard clam M. lusoria for a disease-free and disease-induced SIM dynamics. (B) Process of hard clam M. lusoria exposed to Hg and virus showing disease transmission, mortality, and production sequentially within-summer of the year (see Table 1 for detail symbol descriptions).

could be constructed and described by using a statespace representation as (Fig. 1A),

$$
\left\{\begin{array}{l}
n_{1} \\
n_{2} \\
n_{3} \\
n_{4}
\end{array}\right\}(t+1)=\left[\begin{array}{cccc}
P_{1} & 0 & F_{3} & F_{4} \\
G_{1} & P_{2} & 0 & 0 \\
0 & G_{2} & P_{3} & 0 \\
0 & 0 & G_{3} & P_{4}
\end{array}\right]\left\{\begin{array}{l}
n_{1} \\
n_{2} \\
n_{3} \\
n_{4}
\end{array}\right\}(t)
$$

where $n_{i}(t)$ is the number of hard clam in stage $i$ at time $t$ and matrix $[A]$ is a population projection matrix where
$P_{i}$ is the probability of surviving and staying in stage $i$, $G_{i}$ is the probability of surviving and growing from stage $i$ to stage $i+1$, and $F_{i}$ is the per capita fertility of stage $i$ within each projection interval in that $P_{i}, G_{i}$, and $F_{i}$ are referred to as the life cycle parameters or transition probabilities. Matrix $[A]$ can be used to estimate an asymptotic population growth rate, $\lambda$ (the dominant eigenvalue of $[A]$ ), reflecting the temporal trend in population abundance (Caswell, 2001). When $\lambda$ exceeds 1.00 , the population was projected to increase over time, whereas the population was projected to decline when $\lambda$ 
Table 1

Mathematical expressions of Hill model, transmission probabilities in $[A]$, and West growth model used in the paper (see Table 2 for detail symbol meanings)

Hill concentration-response model

$M(t)=\frac{M_{\max } C_{f}^{n}(t)}{[\operatorname{CL} 50(t)]^{n}+C_{f}^{n}(t)}$

$C_{f}(t)=\mathrm{BCFC}_{w}\left(1-e^{-k_{2} t}\right)$

$\operatorname{CL50}(t)=\frac{\operatorname{DL} 50 / k_{\alpha}}{\left(\frac{e^{-k_{r} t}-e^{-k_{2} t}}{k_{r}-k_{2}}+\frac{1-e^{-k_{2} t}}{k_{r}}\right)}\left(1-e^{-k_{2} t}\right)$

Transition probabilities

$P_{i}=\sigma_{i}\left(1-\gamma_{i}\right)$ (probability of surviving and staying, day ${ }^{-1}$ )

$G_{I}=\sigma_{i} \gamma_{i}$ (probability of surviving and growing, day ${ }^{-1}$ )

$F_{i}=f_{e i} E F_{m i}$ (fertility of stage $i$ within each interval, day ${ }^{-1}$ )

$\sigma_{i}=\frac{S_{i}(t+T)\left(1-M_{i}(t)\right)}{S_{I}(t) T}$ (probability of vital rate of survival, day ${ }^{-1}$ )

$\gamma_{i}=\frac{W_{i}(t+T)-W_{i}(t)}{W_{I}(t) T} \times 100$ (probability of vital rate of growth, day ${ }^{-1}$ )

$S(t)=\left(\frac{1-a t}{1+b t}\right)^{k}$ (intrinsic survival rate)

$f_{e i}=\frac{d F_{e i}(t)}{F_{e 0} d t} \times 100$ (number of eggs per mature female per unit time, day ${ }^{-1}$ )

$F_{e}(t)=m_{0}[W(t)]^{n_{0}}$ (fecundity at age $t$ )

West growth model

$W(t)=W_{\max 0}\left\{1-\left[1-\left(\frac{W_{0}}{W_{\max 0}}\right)^{1 / 4}\right] e^{-A_{0} t / 4 W_{\max 0}^{1 / 4}}\right\}$

MOA1 : $W(t)=W_{\max }\left\{1-\left[1-\left(\frac{0.05}{W_{\max }}\right)^{1 / 4}\right] e^{-A_{0} t / 4 W_{\max }^{1 / 4}}\right\}^{4}$

$$
W_{\max }=W_{\max 0}\left(1-b\left(C_{f}(t)-\mathrm{IEC} 10\right)\right)
$$

MOA2 : $W(t)[1+s(t)]=52.5\left\{1-\left[1-\left(\frac{0.05}{52.5}\right)^{1 / 4}\right] e^{-A_{0} t / 4 \times 52.5^{1 / 4}}\right\}^{4}$

MOA3 $: W(t)=52.5\left\{1-\left[1-\left(\frac{0.05}{52.5}\right)^{1 / 4}\right] e^{-A t / 4 \times 52.5^{1 / 4}}\right\}^{4}$

$A=A_{0}(1+s(t))^{-1}$

\footnotetext{
a Adapted from Caswell (2001).

b Adapted from Simas et al. (2001).

c Adapted from Chen and Liao (2004).

d Adapted from Klok and De Roos (1996).

${ }^{\mathrm{e}}$ Adapted from Blanchard et al. (2003).
}

is less than 1.00. Population growth rate; $\lambda$ was analogy of " $r$," the intrinsic growth rate of increase: $r=\ln \lambda$. Table 1 summarizes the essential mathematical equations of the life cycle parameters of $P_{i}, G_{i}$, and $F_{i}$.

A three-parameter Hill equation model (Eq. (T-1), Table 1) was used to describe the relationship between hard clam whole body burden and mortality to estimate the stage-specific vital rate of survival probability in Eq. (T-4) (Table 1). The time-dependent damage-based lethal body concentration (CL50(t)) in Eq. (T-1) (Table 1) could be derived from the first-order damage accumulation model or known as damage assessment model (DAM) (Eq. (T-3), Table 1) (Bedaux and Kooijman, 1994; Lee et al., 2002). 
The West ontogenetic model was adapted as hard clam growth model under nonexposed conditions (West et al., 2001) (Eq. (T-12) in Table 1). West et al. (2001) developed a mechanistic model to describe ontogenetic growth trajectories of organisms instead of the conventional growth model based on the biometric approach. West growth model was a general quantitative model based on fundamental principles for the utilization of the consumed energy between maintenance of existing tissue and the reproduction of new biomass that had described the growth of many diverse species successfully (West and Brown, 2004). The model characterized the slowing of growth as the body size increases to limitations on the capacity to supply sufficient resources to support further increase in body mass.

In light of DEBtox theory (Jager et al., 2004) and energetics of freshwater clam (Jokela et al., 1993), three modes of toxic action was distinguished on the $\mathrm{Hg}$ growth inhibition of hard clam population model (Fig. 1A): (1) before production of offspring, uninfected hard clams allocated energy to shell growth and glycogen storage, i.e., increase growth cost (MOA3) on embryo/larva and sub-adult stages; (2) during offspring production shell growth slows down, hard clams lost weight and consume the stored glycogen, i.e., decreased assimilation (feeding) (MOA1) on adult stage; and (3) the fat content of hard clams increased on juveniles indicating increased the maintenance costs (MOA2) on that stage. The basic assumption of the DEBtox theory was that chemicals had to be uptake by the organism firstly before they could exert an effect. Once the chemical got inside the target tissues, it increased the probability of adverse response and affected a parameter of the general ontogenetic growth model (e.g., the assimilation rate). Kooijman and Bedaux (1996) and Péry et al. (2003) introduced a stress function $s(t)=b\left[C_{f}(t)-\right.$ IEC $10(t)]$ to describe the extent of adverse effect. IEC 10 is the $10 \%$ effect threshold for chronic growth inhibition and $b$ accounts for the level of toxicity $\left(\mathrm{g} \mathrm{g}^{-1}\right)$ for $C_{\mathrm{f}}$ exceeds IEC10.

We defined mechanistically the MOA1, MOA2, and MOA3 as follows (Table 1) (Tsai and Liao, 2006). MOA1: When feeding was decreasing, growth reduction acted through reducing the incoming energy. The maximum assimilation rate did not appear in the West growth model, yet it could be captured by the maximum weight $\left(W_{\max }\right)$ as suggested by Kooijman and Bedaux (1996) (Eq. (T-13), Table 1). MOA2: When maintenance energy cost was increasing, chemicals were likely to increase in maintenance costs for compensating for the effects of exposure (Beyers et al., 1999). Because maintenance cost had priority over growth, such an increase led to a reduction of growth rate. Body weight was multiplied by $(1+s(t))$ to account for an increase in the maintenance costs, resulting in the reduction of time-dependent body weight as suggested by Kooijman and Bedaux (1996) (Eq. (T-14), Table 1). MOA3: In case of increase growth energy cost, i.e., $C_{\mathrm{f}}$ exceeded IEC10, we assumed that the metabolic energy $\left(E_{\mathrm{c}}\right)$ required to create a new cell were multiplied by $(1+s(t))$ and could be expressed as $E_{\mathrm{c}}=E_{\mathrm{c} 0}(1+s(t))$ where $E_{\mathrm{c} 0}$ was the growth energy cost in control condition. When $C_{\mathrm{f}} \leq \mathrm{IEC} 10$, it led to $s(t)=0$ and $E_{\mathrm{c}}=E_{\mathrm{c} 0}$ (Eq. (T-15), Table 1).

\subsection{Hard clam-Hg-birnavirus system}

Here the disease model was built around the biology of a particular hard clam (M. lusoria)-Hg-stressed birnavirus system to explore the interaction between environmental chemical stressor and disease transmission explaining the host-pathogen interactions presented in the immunomodulating chemicals contaminated aquaculture systems. We used interplay between a nonlinear disease model and published laboratory experiments to parameterize the $M$. lusoria- $\mathrm{Hg}$ stressed birnavirus system. Chou et al. (1998) indicated that the hard clam M. lusoria that are cultured in Taiwan have suffered high mortality each spring/summer since 1969. Here we presumed that the disease-related processes of transmission and production of infected individuals occurred during summer to construct the model presenting the sequence of the events during a year (Fig. 1B).

A disease-induced mortality-based susceptibleinfectious-mortality (SIM) model was used to capture the essence of this $M$. lusoria-Hg-stressed birnavirus system. We used a deterministic SIM model with homogeneous mixing to estimate the force of infection. The dynamics of the susceptible $(S)$, the infected $(I)$, and the mortality state $(M)$ for hard clams exposed to a pollution-stressed disease could be described as (Fig. 1B),

Embryo/larva:

$$
\begin{aligned}
& \frac{d S_{1}}{d t}=S_{3} F_{3}+S_{4} F_{4}-S_{1}\left(1-P_{1}\right)-\lambda_{F_{1}}\left(S_{1} P_{1}\right) \\
& \frac{d I_{1}}{d t}=\lambda_{F_{1}}\left(S_{1} P_{1}\right)+I_{3} F_{3}^{\prime}+I_{4} F_{4}^{\prime}-I_{1}\left(1-P_{1}^{\prime}\right)-\alpha_{1}\left(I_{1} P_{1}^{\prime}\right), \\
& \frac{d M_{1}}{d t}=\alpha_{1}\left(I_{1} P_{1}^{\prime}\right)
\end{aligned}
$$


Juvenile:

$\frac{d S_{2}}{d t}=S_{1} G_{1}-S_{2}\left(1-P_{2}\right)-\lambda_{F_{2}}\left(S_{2} P_{2}\right)$

$\frac{d I_{2}}{d t}=\lambda_{F_{2}}\left(S_{2} P_{2}\right)+I_{1} G_{1}^{\prime}-I_{2}\left(1-P_{2}^{\prime}\right)-\alpha_{2}\left(I_{2} P_{2}^{\prime}\right)$,

$\frac{d M_{2}}{d t}=\alpha_{2}\left(I_{2} P_{2}^{\prime}\right)$

Sub-adult:

$\frac{d S_{3}}{d t}=S_{2} G_{2}-S_{3}\left(1-P_{3}\right)-\lambda_{F_{3}}\left(S_{3} P_{3}\right)$

$\frac{d I_{3}}{d t}=\lambda_{F_{3}}\left(S_{3} P_{3}\right)+I_{2} G_{2}^{\prime}-I_{3}\left(1-P_{3}^{\prime}\right)-\alpha_{3}\left(I_{3} P_{3}^{\prime}\right)$,

$\frac{d M_{3}}{d t}=\alpha_{3}\left(I_{3} P_{3}^{\prime}\right)$

Adult:

$\frac{d S_{4}}{d t}=S_{3} G_{3}-S_{4}\left(1-P_{4}\right)-\lambda_{F_{4}}\left(S_{4} P_{4}\right)$

$\frac{d I_{4}}{d t}=\lambda_{F_{4}}\left(S_{4} P_{4}\right)+I_{3} G_{3}^{\prime}-I_{4}\left(1-P_{4}^{\prime}\right)-\alpha_{4}\left(I_{4} P_{4}^{\prime}\right)$,

$\frac{d M_{4}}{d t}=\alpha_{4}\left(I_{4} P_{4}^{\prime}\right)$

where $P_{i}^{\prime}, G_{i}^{\prime}$, and $F_{i}^{\prime}$ are probabilities of surviving and staying, surviving and growing, and fertility within each projection interval in stage $i$ at an infected condition. The force of infection, $\lambda_{\mathrm{F}}$, that is the infection pressure experienced by one susceptible individual is then given by $\lambda_{F}=\beta(C) I(t)$ where $\beta(C)$ is the concentration $(C)$ dependent transmissibility, and $\alpha(C)$ is the $C$-dependent disease-specific mortality rate (Liao et al., 2006).

Pollution-stressed basic reproductive number $\left(R_{0}(C)\right)$ could be calculated based on $\beta(C)$ and $\alpha(C)$ (Anderson and May, 1991),

$R_{0}(C)=\frac{N(0) \beta(C)}{\alpha(C)}$,

where $N(0)$ is the initial host population size (ind). The relationship between $I$ and $R_{0}(C)$ could be revealed by a fitted equation for $R_{0}(C)$ ranging from 0.98 to 5 as (Liao et al., 2006),

$I=1-\exp \left(1.63-1.66 R_{0}(C)\right)$.
The effect of environmental stressor on host susceptibility and subsequently modulation of disease dynamics in hard clam populations could be characterized by a nonlinear pollution-stressed population dynamics of disease model (Liao et al., 2006),

$$
\begin{aligned}
& N(t+1) \\
& \quad=N(t) \exp \left[(\ln \lambda(C)+1.63)\left(1-\frac{1.66}{\left(\frac{1.63+\ln \lambda(C)}{N \beta(C) / \alpha(C)}\right)}\right)\right],
\end{aligned}
$$

where $N(t+1)$ and $N(t)$ are the population size in generations of $t$ and $t+1$ (ind), and $\lambda(C)$ is the $C$-dependent population growth rate.

\subsection{Reconstructing disease data}

The published data were adopted from the laboratory disease challenge experiments in studying the effects of heavy metal on the susceptibility of hard clam (M. lusoria) to clam birnavirus infection (Chou et al., 1998). Chou et al. (1998) conducted two experiments to examine the effects of $\mathrm{Hg}$ on the disease transmission in hard clam: In experiment I (denoting as $\mathrm{V}+\mathrm{Hg}$ ), group of 60 clams were immersed in birnavirus solution for $24 \mathrm{~h}$ and subsequently exposed to different $\mathrm{Hg}$ concentrations. In experiment II (denoting as $\mathrm{Hg}+\mathrm{V}$ ), clams were exposed to $\mathrm{Hg}$ for 7 days and then infected with birnavirus in that controls were only exposed to $\mathrm{Hg}$. The major results in experiment I indicated that cumulative mortalities of clams were $20-50 \%$ in most of the experimental groups after 5 weeks, whereas in experiment II the survival time shortened and the mortalities ranged from $65 \%$ to $90 \%$.

The best fitted model of $\mathrm{Hg}$-specific transmission and mortality rates based on mortality data obtained from the laboratory disease challenge experiments (Chou et al., 1998) had the form as: $y=a(1-1 /(1+a b x))$ (Liao et al., 2006). For experiment $\mathrm{I}(\mathrm{V}+0.005 \mathrm{ppm} \mathrm{Hg})$ : (1) transmission rate $(\beta): a=0.00980, b=136136.233\left(r^{2}=\right.$ $0.994)$, and $\beta=0.00852(95 \% \mathrm{CI}=0.00736-0.00960)$ day $^{-1}$ ind $^{-1}$ (Fig. 2A) and (2) mortality rate ( $\alpha$ ): $a=$ $0.594, b=2264.239\left(r^{2}=0.994\right)$, and $\alpha=0.517(95 \%$ $\mathrm{CI}=0.444-0.582)$ day $^{-1}$ (Fig. 2B). For experiment II $(0.005 \mathrm{Hg}+\mathrm{V})$ : (1) transmission rate $(\beta): a=0.0231$, $b=49903.576\left(r^{2}=0.992\right)$, and $\beta=0.0197(95 \% \mathrm{CI}=$ $0.0165-0.0226)$ day $^{-1}$ ind $^{-1}$ (Fig. 2C), and (2) mortality rate $(\alpha): a=1.357, b=874.249\left(r^{2}=0.992\right)$, and $\alpha=1.161(95 \% \mathrm{CI}=0.970-1.337)$ day $^{-1}$ (Fig. 2D). The $R_{0}(C)$ estimates for experiments I and II in Hg-stressed 

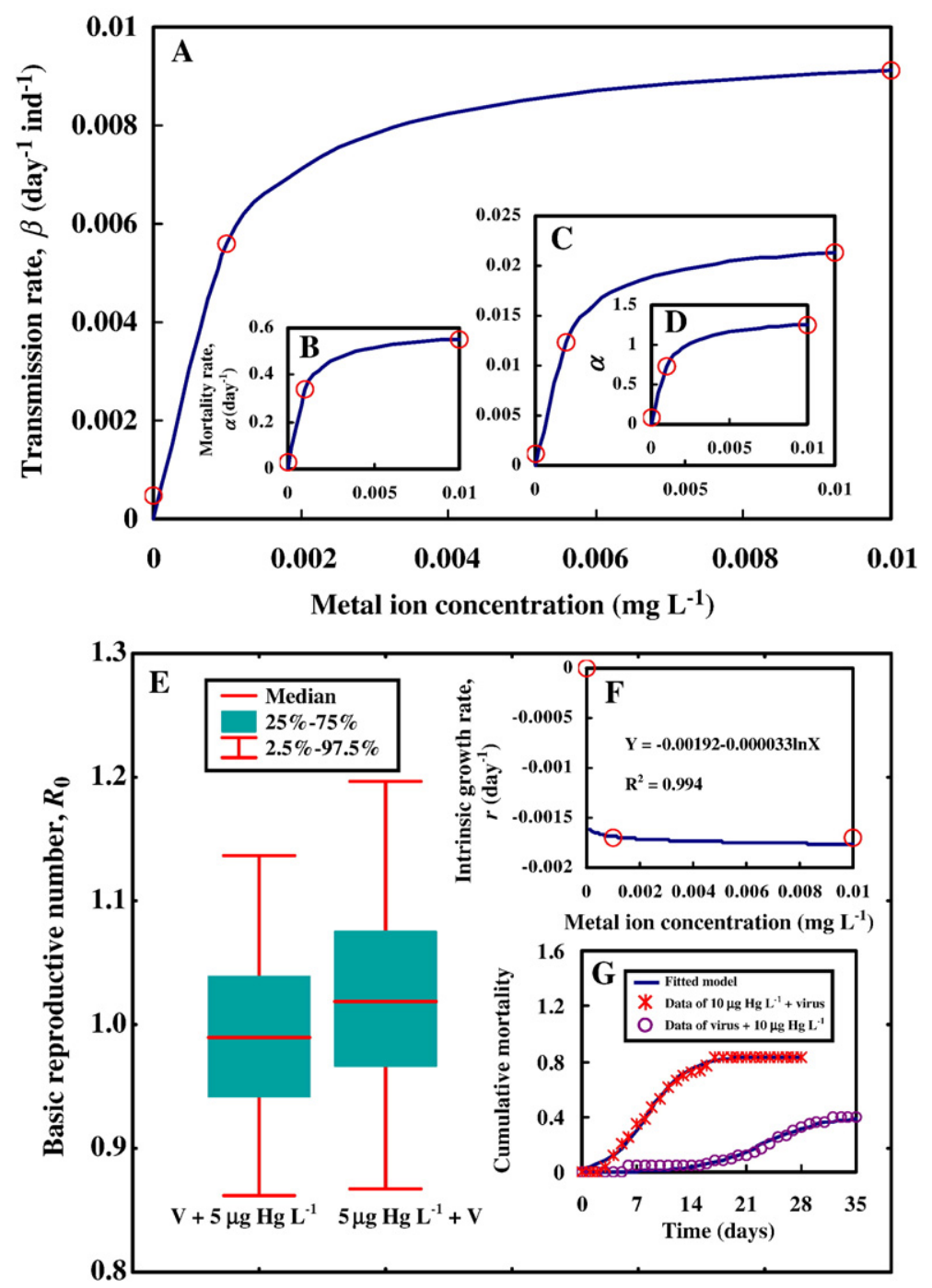

Fig. 2. Estimated disease transmission and mortality rates as a function of $\mathrm{Hg}$ concentrations for experiment I (A, B) and for experiment II (C, D). (E) Box and whisker plot representations of the estimated basic reproductive number $\left(R_{0}\right)$ for $\mathrm{V}+\mathrm{Hg}$ and $\mathrm{Hg}+\mathrm{V}$ settings. (F) Optimal fitted intrinsic growth rate profiles. (G) Time-varying pollution-stressed population dynamics of disease model against the published data of $\mathrm{V}+\mathrm{Hg}$ and $\mathrm{Hg}+\mathrm{V}$ obtained from Chou et al. (1998).

birnavirus infection settings showed the median values were greater than 0.98 (Fig. 2E), indicating that epidemic were potentially spread throughout the hard clam populations without any effective control measures. The Hg-specific population growth rate $(\lambda(C))$ could be estimated by fitting exponential growth model: $\ln (N(t+1) / N(t))=\ln \lambda(C)$ to the published cumulative mortality data (Chou et al., 1998), resulting in a fitted model as: $\ln \lambda(C)=-0.00192-0.000033 \ln C$ $\left(r^{2}=0.994\right)$ (Fig. 2F). We incorporated the above estimated disease data into the pollution-stressed disease model in Eq. (8) to predict cumulative mortality profiles revealing a significantly best fitted with the published cumulative mortality data of experiments I and II in $\mathrm{Hg}$-stressed birnavirus infection settings (Fig. 2G).

\subsection{Vital rate parameters and simulation scheme}

Table 2 gives the used input parameters in estimating vital rates for hard clam populations. To manipulate the simulation of stage-structured population growth model, a projection interval of 1 day was used. Caswell (2001) pointed out that the initial condition had no influence on 
Table 2

Input parameters used to calculate vital rates of individual hard clam

\begin{tabular}{llll}
\hline Growth probability & & & \\
\hline Exposure concentration $\left(\mu \mathrm{g} \mathrm{L}^{-1}\right)$ & Growth cost model, $A_{0}\left(\mathrm{~g}^{1 / 4}\right.$ day $\left.^{-1}\right)$ & Maintenance cost model, $s(t)$ & Feeding decrease model, $W_{\text {max }}(\mathrm{g})$ \\
\hline 0 & $0.0277 \pm 0.00053^{\mathrm{a}}$ & 0 & $38.23 \pm 4.60$ \\
5 & $0.0272 \pm 0.00050$ & $0.047 \pm 0.045$ & $37.52 \pm 4.51$ \\
10 & $0.0271 \pm 0.00051$ & $0.057 \pm 0.047$ & $37.38 \pm 4.50$ \\
30 & $0.0267 \pm 0.00053$ & $0.096 \pm 0.052$ & $36.79 \pm 4.43$ \\
60 & $0.0263 \pm 0.00056$ & $0.135 \pm 0.057$ & $36.19 \pm 4.36$
\end{tabular}

Survival probability

\begin{tabular}{|c|c|}
\hline$a$ (constant) & 0.00104 \\
\hline$b$ (constant) & 0.017 \\
\hline$k^{\mathrm{b}}($ constant $)$ & 0.365 \\
\hline$M_{\max }(\%)$ (maximum mortality rate) & 100 \\
\hline$n^{\mathrm{c}}($ Hill coefficient $)$ & 2.31 \\
\hline $\mathrm{BCF}\left(\mathrm{mL} \mathrm{g}^{-1}\right)^{\mathrm{d}}$ (bioaccumulation factor) & 1417 \\
\hline$K_{2}$ (day $\left.^{-1}\right)^{\mathrm{e}}$ (depuration rate constant) & 0.0343 \\
\hline $\begin{array}{l}D_{\mathrm{L}, 50} / k_{\mathrm{a}}\left(\mu \mathrm{g} \mathrm{h} \mathrm{g}^{-1}\right)^{\mathrm{f}} \text { (coefficient reflects compound equivalent toxic damage } \\
\text { level required for } 50 \% \text { mortality where } k_{\mathrm{a}} \text { is uptake rate constant) }\end{array}$ & 14.60 \\
\hline$k_{\mathrm{r}}\left(\mathrm{h}^{-1}\right)^{\mathrm{f}}$ (damage recovery rate constant) & 4.47 \\
\hline
\end{tabular}

Fertility

$F_{\mathrm{m}}(\%)(\%$ of mature female $)$

$E(\%)$ (egg eclosion rate)

$m_{0}{ }^{\mathrm{g}}$ (fitted coefficient)

70

90

$0.81 \pm 0.023$

$n_{0}{ }^{\mathrm{g}}$ (fitted coefficient)

\footnotetext{
Median \pm SD.

b Adapted from Klok and De Roos (1996).

${ }^{c}$ Estimated from Chin and Chen (1993a) by fitting time-dependent mortality then estimating Hill coefficient $n$ by fitting the Hill model.

d Estimated based on Chin and Chen (1993b).

e Calculated from $k_{2}=\ln 2 / t_{1 / 2}$ where $t_{1 / 2}$ value is adapted from Chin and Chen (1993b).

${ }^{\mathrm{f}}$ Adapted from Tsai (2005).

${ }^{\mathrm{g}}$ Estimated by fitting the relationship between weight and fecundity data from Mzighani (2005) by power function.
}

the stable age distributions as well as population growth rate. Here, 60 hard clams were used as the initial number in each stage in accordance with the experimental condition conducted by Chou et al. (1998). Model simulations and the determinations of asymptotic population growth rate under different scenarios were performed using the MATLAB ${ }^{\circledR}$ software (The Mathworks Inc., MA, USA).

Optimal statistical models were selected on the basis of least squared criterion from a set of generalized linear and nonlinear autoregression models provided by TableCurve 2D package (Version 5, AISN Software Inc., Mapleton, OR, USA) fitted to the data. A value of $p<0.05$ was judged significant. We used a Monte Carlo simulation to quantify our uncertainty. We used the Kolmogorov-Smirnov (K-S) statistics to optimize the goodness-of-fit of distributions. We employed Crystal Ball software (Version 2000.2, Decisioneering, Inc., Denver, CO, USA) to analyze data and to estimate distribution parameters. For this study, 10,000 itera- tions were sufficient to ensure stability of results. The $95 \%$ confidence interval $(\mathrm{CI})$ is defined as the 2.5 th and 97.5th percentiles obtained from the Monte Carlo simulation.

\section{Results}

\subsection{Survivorship and fecundity}

Natural growth rate of M. lusoria in Taiwan could be obtained by fitting West growth model (Eq. (T-12), Table 1) to the published data from Jeng and Tyan (1982) (Fig. 3A). The optimal MOA was determined by fitting Eqs. (T-13) to (T-15) (Table 1) to the published data regarding chronic effects of $\mathrm{Hg}$ on $M$. lusoria growth inhibition (Chin, 1993), resulting in MOA2 of maintenance was the optimal MOA (Fig. 3B). We then used Eq. (T-14) (Table 1) of MOA2 to fit Hg-growth profiles to estimate $\mathrm{Hg}$ concentration-specific vital rate of growth $\left(\gamma_{i}\right)$ by Eq. (T-8) (Table 1) (Fig. 3C). 


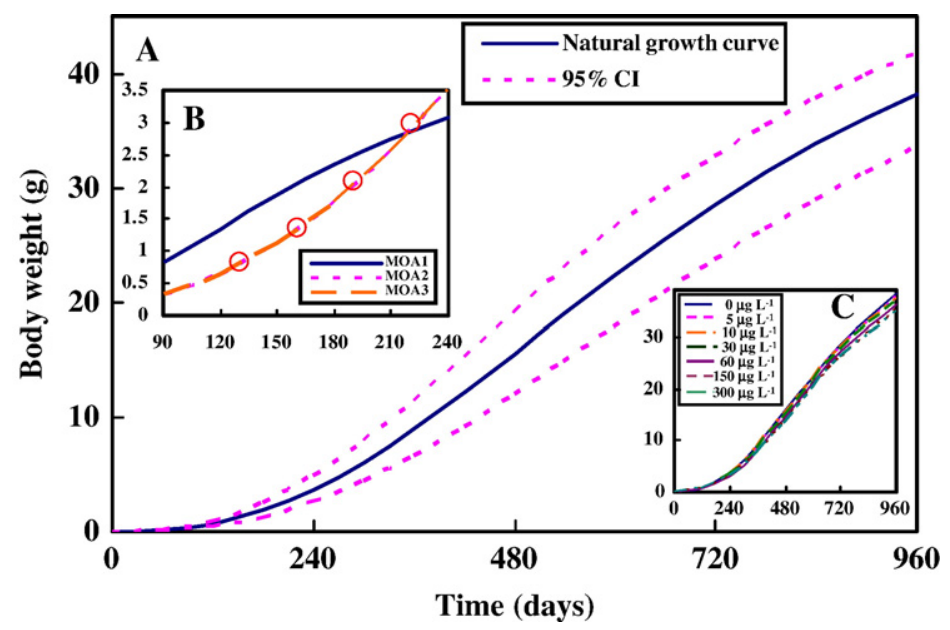

Fig. 3. Natural growth and MOAs in hard clams. (A) Time-dependent natural growth profile of hard clam. (B) Best fits of the feeding decreasing model (MOA1), maintenance cost model (MOA2) and growth cost model (MOA3) in juvenile stage. (C) Simulations of growth trajectory of hard clam life stage vary with different waterborne $\mathrm{Hg}$ concentrations.

Fig. 4A depicts a survival curve for stage-specific hard clam under a nonexposed circumstance by fitting Eq. (T-9) (Table 1) to the natural survival data from Chou et al. (1998). The time-dependent mortality profiles under different $\mathrm{Hg}$ levels (Eqs. (T-1) to (T-3), Table 1) were incorporated into the daily-basis survival probabilities $\left(\sigma_{i}\right)$ (Eq. (T-7), Table 1) of matrix population model to simulate the stage-specific survival proportions for hard clam subject to $\mathrm{Hg}$ concentrations (Fig. 4B, C). Significant changes on hard clam survivorship occurred when the waterborne $\mathrm{Hg}$ concentrations exceeded $10 \mu \mathrm{g} \mathrm{L}^{-1}$ for all life stages in that for juvenile, sub-adult, and adult populations, a notably decline of survival probability was occurred when they exposed to $\mathrm{Hg}$ concentration larger than $10 \mu \mathrm{g} \mathrm{L} \mathrm{L}^{-1}$ (Fig. 4B, C). The infected mortality rate of hard clam could be obtained by fitting Eq. (T-1) (Table 1) to the estimated 960 day cumulative mortality data calculated from the population disease model (Eq. (8)) based on reconstructed infection data (Fig. 2G) and then used Eq. (T-7) (Table 1) to estimate the infected survival probability (Fig. 4D). Fig. 4D indicates that the inhibition potential on stage-specific hard clam population in the experiment II $\left(5 \mu \mathrm{g} \mathrm{L}^{-1} \mathrm{Hg}+\mathrm{V}\right)$ was much higher than that of in the experiment $\mathrm{I}\left(\mathrm{V}+5 \mu \mathrm{g} \mathrm{L}^{-1} \mathrm{Hg}\right)$, whereas birnavirus only had slightly effects on most of hard clam populations.

\subsection{Population abundance without disease}

The temporal changes of stage-specific and overall population abundances of uninfected hard clam ex- posed to different scenarios of waterborne $\mathrm{Hg}$ were illustrated in Fig. 5. Fig. 5 indicates that at relative high concentrations of waterborne $\mathrm{Hg}\left(>30 \mu \mathrm{g} \mathrm{L}^{-1}\right)$ the population abundance decreases sharply. The high risk of mortality was likely due to the relatively low overall population growth rate (Fig. 6A, B). In the absence of disease, population growth rates $(\lambda)$ of hard clam populations in response to $\mathrm{Hg}$ concentration showed a significant reduction when $\mathrm{Hg}$ concentration higher than $10 \mu \mathrm{g} \mathrm{L}^{-1}$ (Fig. 6A). A reference value of $\lambda=1.0008$ (95\% CI: $0.9985-1.0053$ ) was obtained for the population growth rate in the absence of $\mathrm{Hg}$ concentration, indicating a potential growth population. A stable growth for hard clam populations was shown at the $\mathrm{Hg}$ concentrations of $10 \mu \mathrm{g} \mathrm{\textrm {L } ^ { - 1 }}$ (Fig. 6A). Fig. 6A also demonstrates that the population growth rate decreased from $\lambda=1.0008$ for the control group to $\lambda=0.9163$ (95\% CI: $0.8818-0.9527$ ) for hard clam populations exposed to waterborne $\mathrm{Hg}$ higher than $30 \mu \mathrm{g} \mathrm{L}^{-1}$, indicating at high levels of environmental $\mathrm{Hg}$ stressor increased the risk of mortality very considerably (Fig. 6A, B).

In addition, we used three-parameter Hill equation model (Eq. (T-1), Table 1) to reconstruct a concentration-response profile between reduction in population abundance and waterborne $\mathrm{Hg}$ for hard clam populations after a 1-year simulation (Fig. 6C) in that the simulation time period was determined from a pre-analysis for the control population to reach its stable age distribution. The optimal fits of Eq. (T-1) (Table 1) to the predicted percent reduction in population abundance of hard clam versus waterborne $\mathrm{Hg}$ concentration resulted in the 

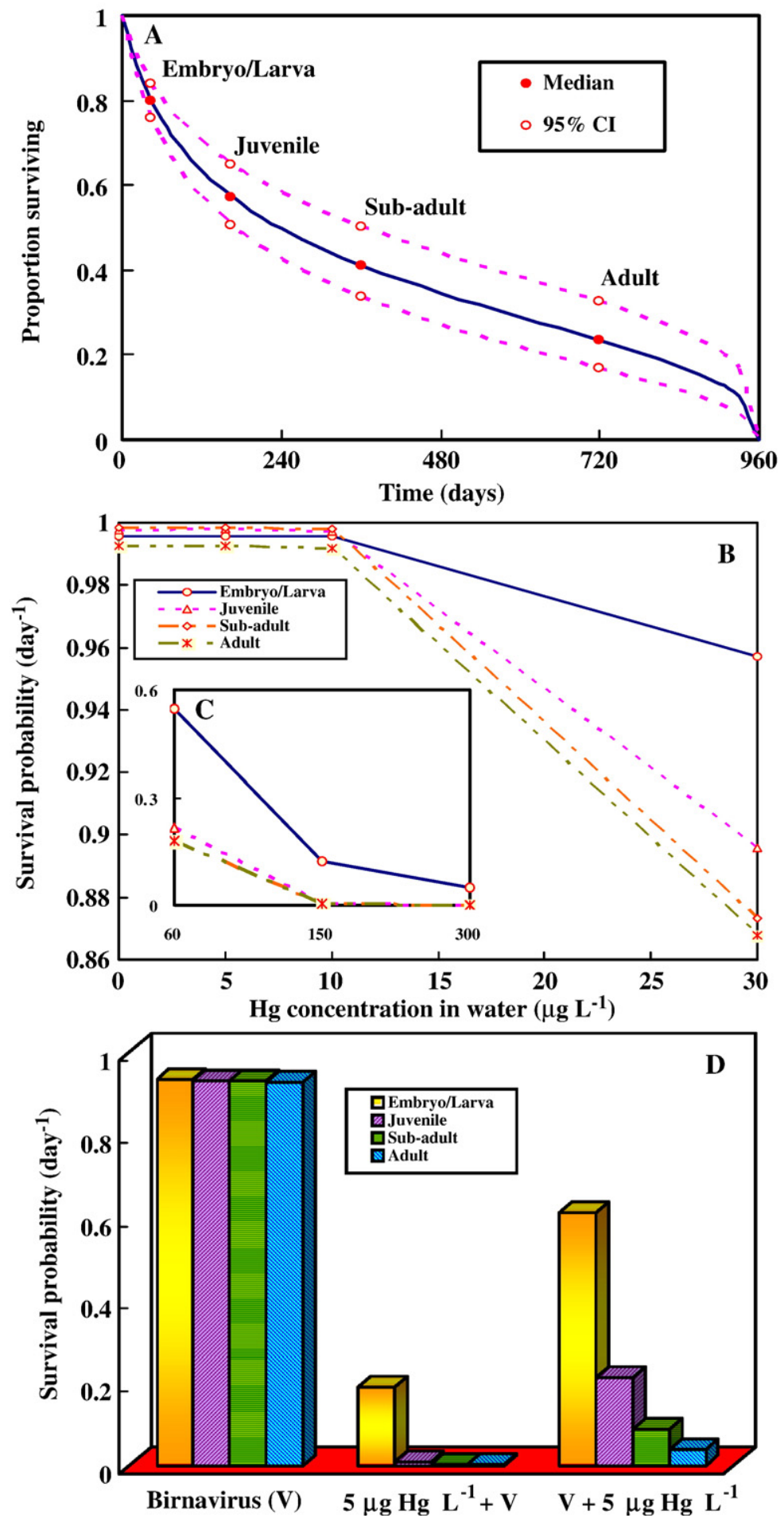

Fig. 4. Survival probability in hard clam populations. A four-stage survival of hard clam for (A) under natural circumstances, and exposed to (B) 0 to $30 \mu \mathrm{g} \mathrm{L}^{-1}$ and (C) 60 to $300 \mu \mathrm{g} \mathrm{L}^{-1}$ waterborne $\mathrm{Hg}$ concentrations, and (D) exposed to virus only, $\mathrm{V}+\mathrm{Hg}$, and $\mathrm{Hg}+\mathrm{V}$ settings. 

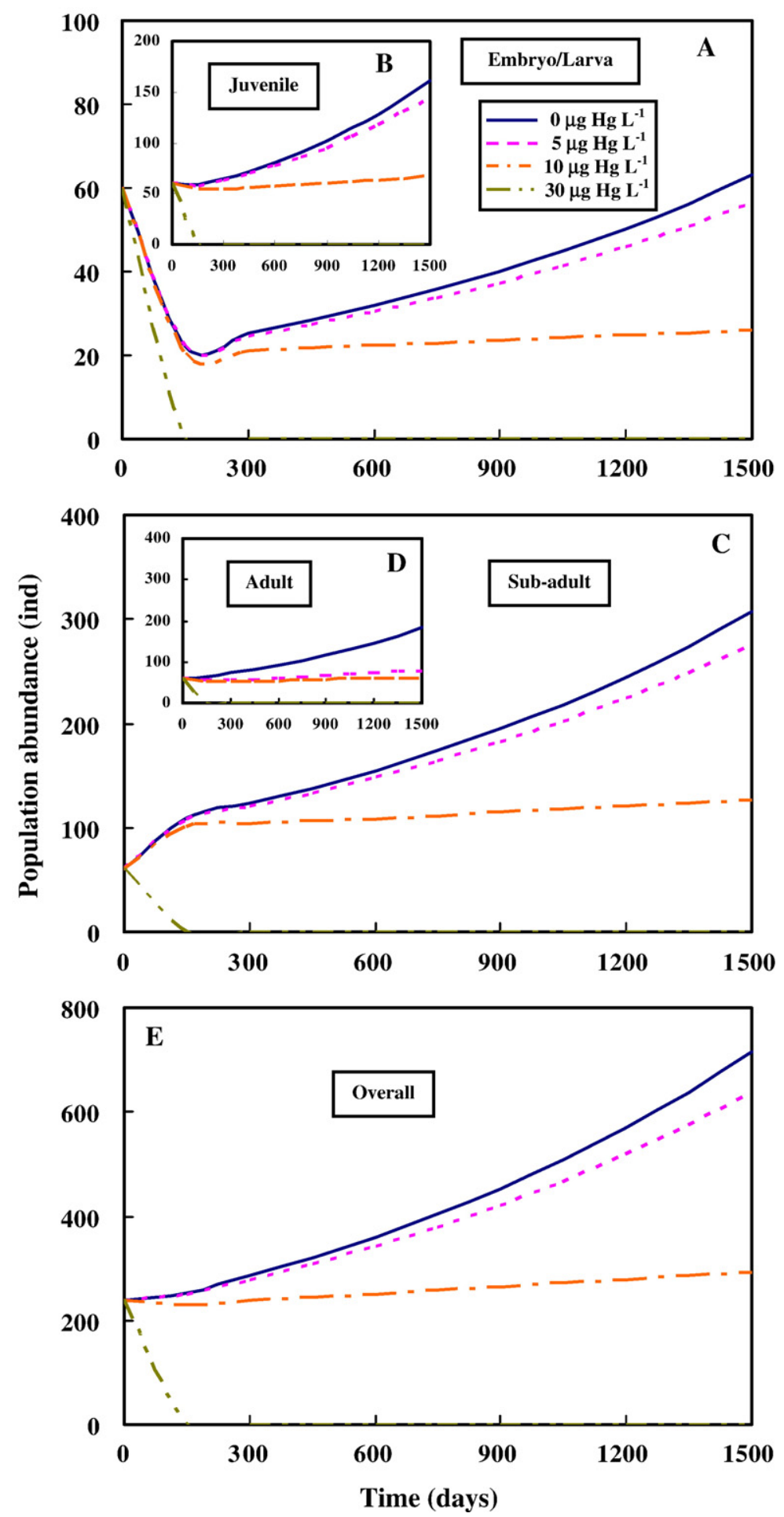

Fig. 5. Hard clam population abundances without disease. Temporal changes in life stages in (A) Embryo/larva, (B) juveniles, (C) sub-adults, (D) adults, and (E) overall population abundances of hard clam exposed to waterborne $\mathrm{Hg}$ concentrations ranging from 0 to $30 \mu \mathrm{g} \mathrm{L}{ }^{-1}$. 

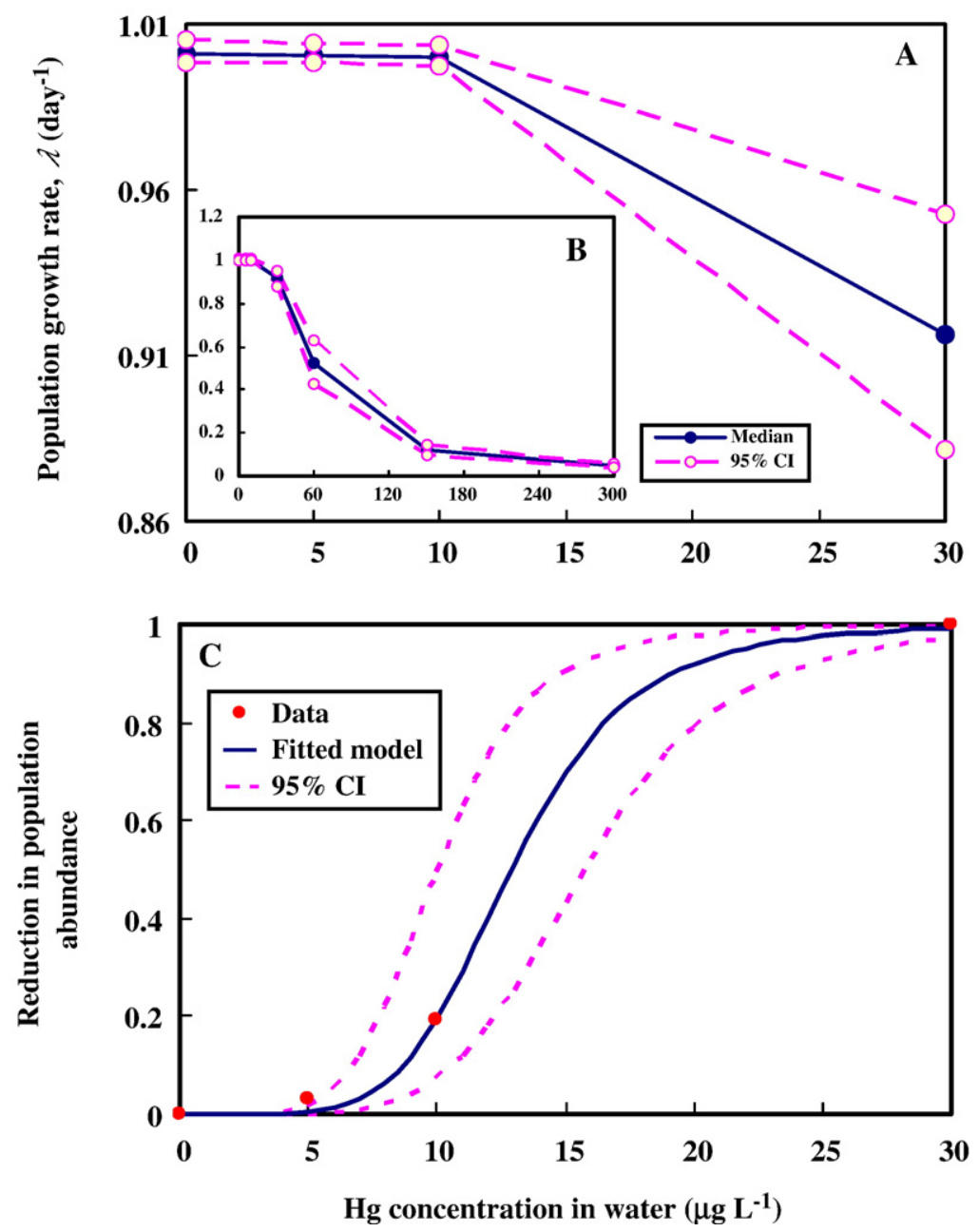

Fig. 6. Population growth rate and concentration-response relationship. Asymptotic population growth rate is expressed as a function of exposure Hg concentrations of (A) 0 to $30 \mu \mathrm{g} \mathrm{L}^{-1}$ and (B) 0 to $300 \mu \mathrm{g} \mathrm{L}{ }^{-1}$. (C) A Hill-based dose-response model showing the reduction in population abundance profiles as the function of waterborne mercury concentration for 1-year simulation.

estimated effect concentration causing $50 \%$ reduction EC50 $=12.91 \mu \mathrm{g} \mathrm{L}^{-1}$ and Hill coefficient $n=5.59$ $\left(r^{2}=0.99, p<0.05\right)$, indicating a high cooperativity.

\subsection{Population abundance with disease}

The results based on model simulations by integrating stage-structured matrix population and SIM model revealed that different experimental settings had significantly different population abundance dynamics based on $N_{i}(0)=60$ (Figs. 7 and 8). The model predicted that, in $5 \mu \mathrm{g} \mathrm{Hg} \mathrm{L}^{-1}+\mathrm{V}$ setting, all the stages of hard clam populations decreased sharply nearly $80 \%$ of control number at day 30 , then steadily grew to the end of the year (Fig. 7B). The predicted results were sensitive to substantial changes in the value of transmission rate that would affect dynamics most strongly and even to changes in aspects of model structure (Fig. 8). The result also indicated that decreased by $20-80 \%$ of transmission rate changed population abundance predictions significantly in $5 \mu \mathrm{g} \mathrm{Hg} \mathrm{L}^{-1}+\mathrm{V}$ setting (Fig. 8B). In order to understand the effect of host size on the disease epidemics, three scenarios associated with different transmission rates were incorporated into the model to predict the basic reproduction number $\left(R_{0}\right)$ and allowance population number $\left(N^{*}\right)$ to control the outbreak (Table 3). Table 3 indicates that at relative low disease transmission rate $(50 \%$ decreased), the allowance rearing numbers of hard clam to control the potential outbreak are 389 and 298, respectively, in the $5 \mu \mathrm{g} \mathrm{Hg}$ $\mathrm{L}^{-1}+\mathrm{V}$ and $\mathrm{V}+5 \mu \mathrm{g} \mathrm{Hg} \mathrm{L}{ }^{-1}$ settings with the $R_{0}$ around 1.15-1.19. Table 3 also implicates that limitation of host 

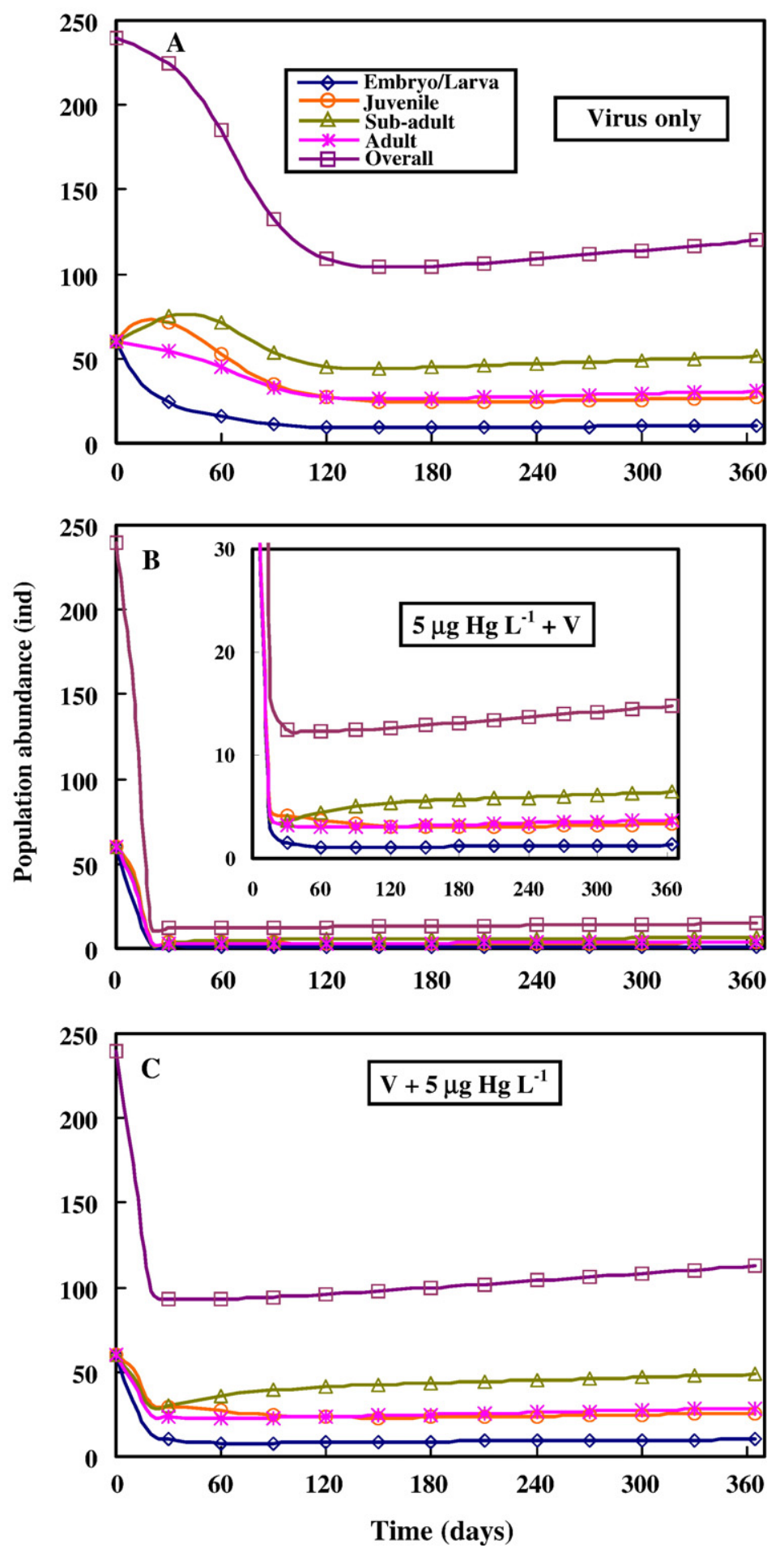

Fig. 7. Population abundance dynamics with disease. Hard clam populations that are affected by (A) virus only, (B) $5 \mu \mathrm{g} H g \mathrm{~L}^{-1}+\mathrm{virus}$ and (C) virus $+5 \mu \mathrm{g} \mathrm{Hg} \mathrm{L}^{-1}$ in that simulations for disease-induced infection were one time after 1 year. 

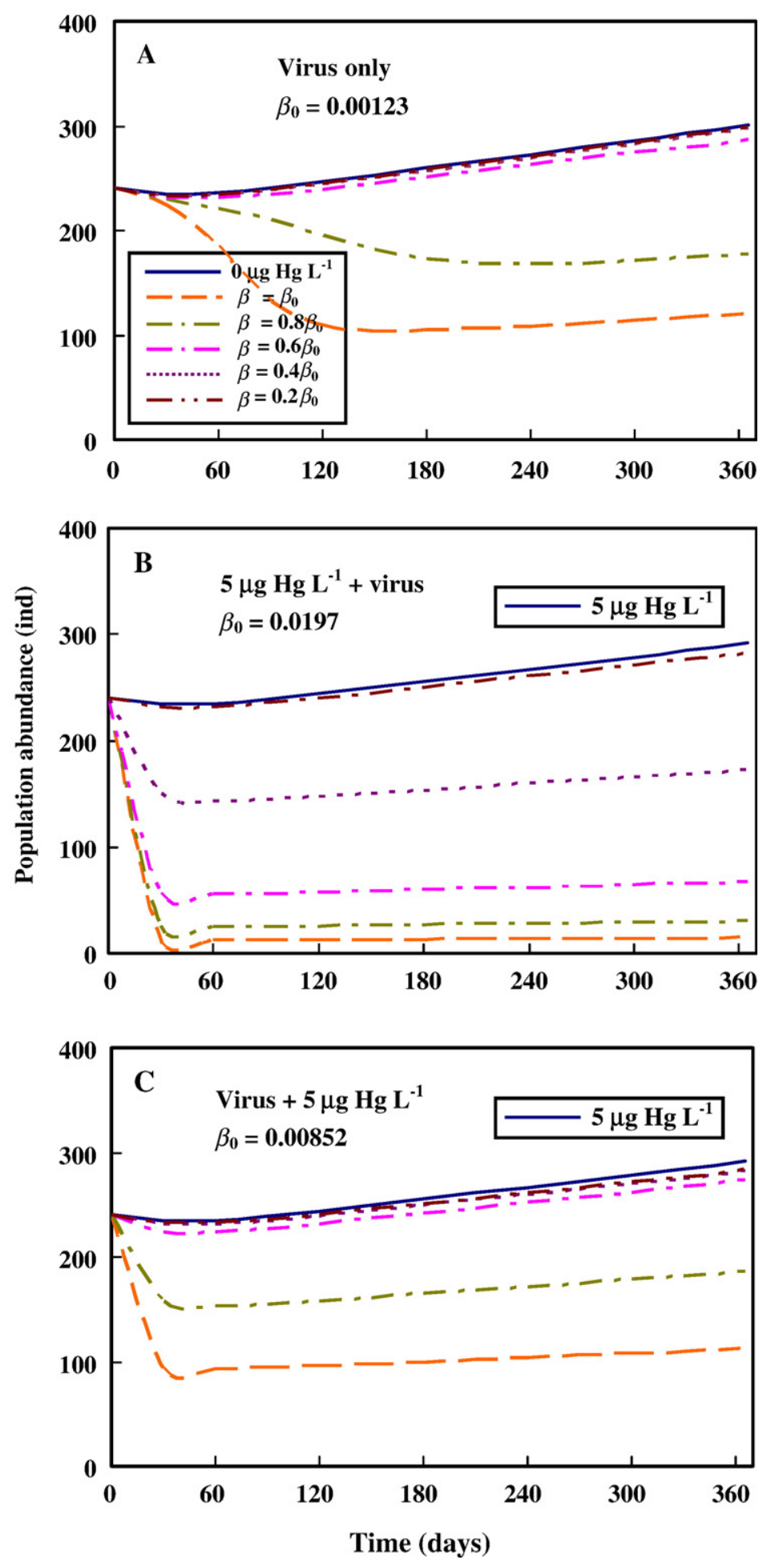

Fig. 8. Controls on hard clams to Hg-stressed birnavirus susceptibility. Control strategies is expressed as the function of transmissibility for different scenarios of (A) virus only, (B) $5 \mu \mathrm{g} \mathrm{Hg} \mathrm{L}{ }^{-1}+$ virus, and (C) virus $+5 \mu \mathrm{g} \mathrm{Hg} \mathrm{L}^{-1}$ in reducing disease-induced transmission rate and in improving population abundances of hard clam. 
Table 3

Scenario-dependent basic reproductive number estimates and estimated allowance numbers to control outbreak based on three scenarios of virus (V) only, $5 \mu \mathrm{g} \mathrm{Hg} \mathrm{L}^{-1}+\mathrm{V}$, and $\mathrm{V}+5 \mu \mathrm{g} \mathrm{Hg} \mathrm{L}{ }^{-1}$ varied with transmission rate $(\beta)$

\begin{tabular}{|c|c|c|}
\hline $\begin{array}{l}\text { Transmission rate } \\
\left(\text { day }^{-1} \text { ind }^{-1}\right)\end{array}$ & $\begin{array}{l}\text { Basic reproductive } \\
\text { Number }\left(R_{0}\right)\end{array}$ & $\begin{array}{l}\text { Allowance numbers to } \\
\text { control outbreak }\left(N^{*}\right)\end{array}$ \\
\hline \multicolumn{3}{|l|}{ Virus only $^{\mathrm{a}}$} \\
\hline$\beta=\beta_{\mathrm{v}}$ & 5.74 & 60 \\
\hline$\beta=0.8 \beta_{\mathrm{v}}$ & 4.59 & 75 \\
\hline$\beta=0.6 \beta_{\mathrm{v}}$ & 3.44 & 100 \\
\hline$\beta=0.4 \beta_{\mathrm{v}}$ & 2.30 & 150 \\
\hline$\beta=0.5 \beta_{\mathrm{v}}$ & 1.15 & 300 \\
\hline \multicolumn{3}{|l|}{$5 \mu \mathrm{g} \mathrm{Hg} \mathrm{L}^{-1}+\mathrm{V}^{\mathrm{a}}$} \\
\hline$\beta=\beta_{5+\mathrm{v}}$ & 5.94 & 58 \\
\hline$\beta=0.8 \beta_{5+\mathrm{v}}$ & 4.75 & 72 \\
\hline$\beta=0.6 \beta_{5+\mathrm{v}}$ & 3.56 & 96 \\
\hline$\beta=0.4 \beta_{5+\mathrm{v}}$ & 2.37 & 144 \\
\hline$\beta=0.5 \beta_{5+\mathrm{v}}$ & 1.19 & 389 \\
\hline \multicolumn{3}{|l|}{$\mathrm{V}+5 \mu \mathrm{g} \mathrm{Hg} \mathrm{L}^{-1 \mathrm{a}}$} \\
\hline$\beta=\beta_{\mathrm{v}+5}$ & 5.77 & 60 \\
\hline$\beta=0.8 \beta_{v+5}$ & 4.62 & 75 \\
\hline$\beta=0.6 \beta_{\mathrm{v}+5}$ & 3.46 & 99 \\
\hline$\beta=0.4 \beta_{\mathrm{v}+5}$ & 2.31 & 149 \\
\hline$\beta=0.5 \beta_{\mathrm{v}+5}$ & 1.15 & 298 \\
\hline
\end{tabular}

${ }^{a}$ Adapted from Liao et al. (2006) in that virus (V) only: $\beta=0.00123$, $\alpha=0.0752$, and $N=350 ; 5 \mu \mathrm{g} \mathrm{Hg} \mathrm{L}-1+\mathrm{V}: \beta=0.0197, \alpha=1.161$, and $N=350$; and $\mathrm{V}+5 \mu \mathrm{g} \mathrm{Hg} \mathrm{L}^{-1}: \beta=0.00852, \alpha=0.517$, and $N=350$.

size or carrying capacity was one of the most effective control measures.

\section{Discussion}

\subsection{Dynamics and management of pollution-stressed infection}

Pollution-stressed disease management could be explored through simulation, using our integrated SIMMPM framework. The model could be modified to evaluate the potential efficacy of the disease management strategies. We could further limit the hard clam population number once the outbreak was recognized. In the other strategy, vaccination might be used to protect early-stage hard clam populations (Murray and Peeler, 2005). Because conducting a specific management strategy (such as vaccination) throughout the entire range of hard clam farms often were not be feasible, it was useful to assess feasible strategies. Based on the present findings, we suggested that recognizing which of the scenarios and ranges of disease transmissibility in Table 3 best applying to a given situation can aid in designing the most efficient and feasible disease management strategy.
Having argued for the importance and practical relevance of our control measure framework (Table 3), it was worthwhile to consider how the applicable scenario could be determined in a field situation. Future evaluation might be focused on the relationships between potential influences of disease on survival and reproduction and physiological movement pattern of infected individuals of aquaculture species populations. Such models will also provide tools for evaluating further management alternatives to improve our ability to respond to future disease outbreaks.

Hard clam populations undergoing $\mathrm{Hg}$-stressed birnavirus present a unique spread pattern that led us to study the dynamics of infectious diseases linked with SIM and MPM. Based on theoretical considerations in a parsimonious framework, we outlined three qualitatively distinct scenarios of virus only, metal+virus, and virus + metal. Within a range of disease transmissibility $(\beta)$ drawn from analysis of birnavirus in hard clams, different $\beta$ values led to simulated outbreaks characterized by basic reproductive number $\left(R_{0}\right)$ depicting the allowance population numbers $\left(N^{*}\right)$ to contain disease spread for all three scenarios. Thus, the uncertainty regarding a disease's transmissibility, perhaps inevitable when considering a disease in a new host species or environment, could challenge our ability to assess the likelihood of long-term persistence and the rate of spread within a population, and hence the threat to other life-stage species in the aquaculture systems (Pieters and Liess, 2006).

\subsection{Pathogenesis and host sensitivity to metals}

Not much was known about the life cycles of the birnavirus. Infection intensities might depend on the season (Earn et al., 2000; Harvell et al., 2002). Information of the correlation between the $\mathrm{Hg}$ toxicity and the number of the birnavirus pathogens in hard clams was not available as well. Pathogenic infections might change the host's behavior in such a way that the pathogen's chances to complete its life cycle were enhanced. Pathogenic infections might also disturb the normal feeding behavior or the water-pumping rate in filter-feeding bivalves, which might lower the bioaccumulation of waterborne metals and lead to lower tissue concentrations in infected clams. The effects of pathogenic infection on behavior of the host were shown to depend on the parasite species, but also on the developmental stage of the pathogenesis (Levri and Lively, 1996; Lafferty et al., 2006).

Part of bioaccumulation in gill-breathing aquatic organisms took place in the gills by equilibrium 
partitioning between the water and the lipid phase of the organism (McKim and Erickson, 1991). High temperatures in water generally speed up accumulation because animals increased water ventilation through the gills and the permeability of cell membranes increases. Therefore, the biokinetics in a hard clam-pathogen system was also the important information. Low average temperature and low food availability associated with temperature might result in a reduced growth rate of the clams. Heavy pathogenic infections might also lead to reduce embryo production. In the future work, we might incorporate the present model into a model describing the interplay between temperature-dependent physiology of host-pathogen and predators in order to constrain epidemics to warmer, colder, or intermediate temperatures and further to explain the seasonal phenology of epidemics in aquaculture systems (Heinonen et al., 1999; Hall et al., 2006b).

\subsection{General implications}

The employed MPM was a density-independent growth of a stage-structured population observed at continuous time intervals. Therefore, the effect of the self-limitation was negligible. The density-dependent parameter such as carrying capacity in the present model was not considered. If population project matrix $[A]$ in Eq. (1) was density-dependent that could result in most of the analysis for MPM inapplicable (Caswell, 2001). Populations no longer grow exponentially, and solutions could no longer be written in terms of eigenvalues and eigenvectors. Even the simplest density-dependent models were capable of complex dynamic behaviors, and experiments had confirmed that real populations exhibited at least some of these complexities. The analysis of nonlinear matrix models could be found in Lima et al. (2000).

The current study presented how a mechanistic perspective based on the chemical effects on the aquaculture species energy budget could promote life cycle toxicity assessment. The present study showed that the bioenergetics-based matrix population methodology could be employed in a life cycle toxicity assessment framework to explore the effect of stage-specific MOAs in population response to contaminants (Klanjscek et al., 2006; Péry et al., 2006; Raimondo and McKenney, 2006). An important implication of the study was that we used mathematical models to give population stage-structure and clarity to the analysis of the key population-level endpoints (the population growth rate $(\lambda)$ and stagespecific MOAs) and epidemiological relevant factors (basic reproductive number $\left(R_{0}\right)$ and transmissibility $(\beta))$ of the population dynamics and evaluated the effect of bioenergetics-based MOAs in field hard clam populations in response to pollution-stressed disease. Thus, MOAs and population structure were major variables governing susceptibility of hard clams to pollution-stressed disease.

The present result was based on biologically plausible and empirically grounded dynamical models. The analyses showed that demographic modeling could provide a reasonable analysis of contaminant effects at the population level, even given uncertainty about the structure of the system and the hard clam's response to the environment. The hard clam was a typical example of population-level risk assessment for which only some demographic data were available. Although more complex models might be necessary to answer specific questions regarding risk or particular management strategies, the present simple model captured the essential dynamics and it's flexible enough to integrate effects occurring at varying temporal scales.

The results suggested that even simple models could provide useful insights into complex ecological, toxicological, and epidemiological interactions in aquaculture systems. This was particularly valuable when manipulative experimental work in the field or laboratory at appropriate spatiotemporal scales were often impossible or prohibitively expensive. We were confident that the model could be easily adapted for other aquaculture species and encourage researchers to use the model to evaluate the potential population-level risk of toxic chemicals-stressed pathogen on the population dynamics of disease for these species. Demographic data for many aquaculture species remained untested by modern analysis; the present model should provide an excellent basis for diagnosing population-level status and trends, including estimating mortality and recovery probabilities. The present analysis yielded quantitative insights into the mechanisms and extent of impacts of metal-stressed disease on population dynamics in farm fish populations. More generally, the results informed the development of aquaculture sustainability and disease theory and its application in fisheries and aquaculture management.

\section{References}

Anderson, R.M., May, R.M., 1991. Infectious Diseases of Humans: Dynamics and Control. Oxford University Press, New York, NY. Arkoosh, M.R., Clemons, E., Myers, M., Casillas, E., 1994. Suppression of B-cell mediated immunity in juvenile chinook salmon (Oncorhynchus-tshawytscha) after exposure to either a polycyclic aromatic hydrocarbon or to polychlorinated-biphenyls. Immunopharmacol. Immunotoxicol. 16, 293-314. 
Arkoosh, M.R., Casillas, E., Huffman, P., Clemons, E., Evered, J., Stein, J.E., Varanasi, U., 1998. Increased susceptibility of juvenile chinook salmon from a contaminated estuary to Vibrio anguillarum. Trans. Am. Fish. Soc. 127, 360-374.

Arkoosh, M.R., Clemons, E., Huffman, P., Kagley, A.N., 2001. Increased susceptibility of juvenile chinook salmon to vibriosis after exposure to chlorinated and aromatic compounds found in contaminated urban estuaries. J. Aquat. Anim. Health 13, 257-268.

Bedaux, J.J.M., Kooijman, S.A.L.M., 1994. Stochasticity in deterministic model. In: Rao, C.R., Patil, G.P., Ross, N.P. (Eds.), Handbook of Statistics 12: Environmental Statistics. Elsevier, Oxford, pp. 561-581.

Beyers, D.W., Rice, J.A., Clements, W.H., Henry, C.J., 1999. Estimating physiological cost of chemical exposure: integrating energetics and stress to quantify toxic effects in fish. Can. J. Fish. Aquat. Sci. 56, 814-822.

Blanchard, J.L., Frank, K.T., Simon, J.E., 2003. Effects of condition on fecundity and total egg production of eastern Scotian Shelf haddock (Melanogrammus aeglefinus). Can. J. Fish. Aquat. Sci. 60, 321-332.

Caswell, H., 2001. Matrix Population Models: Construction, Analysis, and Interpretation, 2nd ed. Sinauer Associates, Sunderland, MA, USA.

Chen, B.C., Liao, C.M., 2004. Population models of farmed abalone Haliotis diversicolor supertexta exposed to waterborne zinc. Aquaculture 242, 251-269.

Chin, T.H., 1993. Acute toxicity and chronic effects of mercury on the hard clam, Meretrix lusoria Röding (Bivalva: Veneidae). Ph.D. Dissertation, National Taiwan University.

Chin, T.S., Chen, H.C., 1993a. Toxic effects of mercury on the hard clam, Meretrix lusoria, in various salinities. Comp. Biochem. Physiol. 105C, 501-507.

Chin, T.S., Chen, H.C., 1993b. Bioaccumulation and distribution of mercury in the hard clam, Meretrix lusoria (Bivlavia: Veneidae). Comp. Biochem. Physiol. 106C, 131-139.

Chou, H.Y., Chang, S.J., Lee, H.Y., Chiou, Y.C., 1998. Preliminary evidence for the effect of heavy metal cations on the susceptibility of hard clam (Meretrix lusoria) to clam birnavirus infection. Fish Pathol. 33, 213-219.

Chou, H.Y., Peng, T.Y., Chang, S.J., Hsu, Y.L., Wu, J.L., 1999. Effect of heavy metal stressors and salinity shock on the susceptibility of grouper (Epinephelus sp.) to infectious pancreatic necrosis virus. Virus Res. 63, 121-129.

Earn, D.J., Rojman, P., Bolker, B.M., Grenfell, B.T., 2000. A simple model for complex dynamical transitions in epidemics. Science 287, 667-670.

Forbes, V.E., Sibly, R.M., Calow, P., 2001. Toxicant impacts on density-limited populations: a critical review of theory, practice, and results. Ecol. Appl. 11, 1249-1257.

Hall, A.J., Hugunin, K., Deaville, R., Law, R.J., Allchin, C.R., Jepson, P.D., 2006a. The risk of infection from polychlorinated biphenyl exposure in the harbor porpoise (Phocoena phocoena): a casecontrol approach. Environ. Health Perspect. 114, 704-711.

Hall, S.R., Tessier, A.J., Duffy, M.A., Huebner, M., Caceres, C.E., 2006b. Warmer does not have to mean sicker: temperature and predators can jointly drive timing of epidemics. Ecology 87, 1684-1695.

Harvell, C.D., Mitchell, C.E., Ward, J.R., Altizer, S., Dobson, A.P., Ostfeld, R.S., Samuel, M.D., 2002. Ecology_climate warming and disease risks for terrestrial and marine biota. Science 296, $2158-2162$.
Heinonen, J., Kukkonen, J.V.K., Holopainen, I.J., 1999. The effects of parasites and temperature on the accumulation of xenobiotics in a freshwater clam. Ecol. Appl. 9, 475-481.

Hendriks, A.J., Maas-Diepeveen, J.L.M., Heugens, E.H.W., 2005. Meta-analysis of intrinsic rates of increase and carrying capacity of populations affected by toxic and other stressors. Environ. Toxicol. Chem. 24, 2267-2277.

Jager, T., Crommentuijn, T., Van Gestel, C.A.M., Kooijman, S.A.L.M., 2004. Simultaneous modeling of multiple end points in life-cycle toxicity tests. Environ. Sci. Technol. 38, 2894-2900.

Jeng, S.S., Tyan, Y.M., 1982. Growth of the hard clam Meretrix lusoria in Taiwan. Aquaculture 27, 19-28.

Jokela, J., Uotila, L., Taskinen, J., 1993. Effect of the castrating trematode parasite Rhipidocotyle-fennica on energy allocation of fresh-water clam Anodonta piscinalis. Funct. Ecol. 7, 332-338.

Klanjscek, T., Caswell, H., Neubert, M.G., Nisbet, R.M., 2006. Integrating dynamic energy budgets into matrix population models. Ecol. Model. 196, 407-420.

Klok, C., De Roos, A.M., 1996. Population level consequences of toxicological influences on individual growth and reproduction in Lumbricus rubellus (Lumbricidae, Oligochaeta). Ecotoxicol. Environ. Saf. 33, 118-127.

Kooijman, S.A.L.M., Bedaux, J.J.M., 1996. The Analysis of Aquatic Toxicity Data. VU University Press, Amsterdam, The Netherlands.

Lafferty, K.D., Dobson, A.P., Kuris, A.M., 2006. Parasites dominate food web links. Proc. Natl. Acad. Sci. 103, 11211-11216.

Lee, J.H., Peter, F.L., Koh, C.H., 2002. Prediction of time-dependent PAH toxicity in Hyalella azteca using a damage assessment model. Environ. Sci. Technol. 36, 3131-3138.

Levri, E.P., Lively, C.M., 1996. The effects of size, reproductive condition, and parasitism on foraging behaviour in a freshwater snail, Potamopyrgus antipodarum. Anim. Behav. 51, 891-901.

Liao, C.M., Chang, C.F., Yeh, C.H., Chen, S.C., Chiang, K.C., Chio, C.P., Chou, B.Y.H., Jou, L.J., Lien, G.W., Lin, C.M., Shen, H.H., Wu, G.D., 2006. Metal stresses affect the population dynamics of disease transmission in aquaculture species. Aquaculture 257, 321-332.

Lima, M., Brazeiro, A., Defeo, O., 2000. Population dynamics of the yellow clam Mesodesma mactroides: recruitment variability, density-dependence and stochastic processes. Mar. Ecol., Prog. Ser. 207, 97-108.

Loge, F.J., Arkoosh, M.R., Ginn, T.R., Johnson, L.L., Collier, T.K., 2005. Impact of environmental stressors on the dynamics of disease transmission. Environ. Sci. Technol. 39, 7329-7336.

McKim, J.M., Erickson, R.J., 1991. Environmental impacts on the physiological-mechanisms controlling xenobiotic transfer across fish gills. Physiol. Zool. 64, 39-67.

Murray, A.G., Peeler, E.J., 2005. A framework for understanding the potential for emerging diseases in aquaculture. Prev. Vet. Med. 67, 223-235.

Mzighani, S., 2005. Fecundity and population structure of cockles, Anadara antiquate L. 1758 (Bivalvia: Arcidae) from a sandy/ muddy beach near Dar es Salaam, Tanzania. West. Indian Ocean J. Mar. Sci. 4, 77-84.

Nichols, J.W., Echols, K.R., Tillitt, D.E., Secord, A.L., McCarty, J.P., 2004. Bioenergetics-based modeling of individual PCB congeners in nestling tree swallows from two contaminated sites on the upper Hudson River, New York. Environ. Sci. Technol. $38,6234-6239$.

Oli, M.K., Vnekataraman, M., Klein, P.A., Wendland, L.D., Brown, M.B., 2006. Population dynamics of infectious diseases: a discrete time model. Ecol. Model. 198, 183-194. 
Péry, A.R.R., Ducrot, V., Mons, R., Garric, J., 2003. Modelling toxicity and mode of action of chemicals to analyse growth and emergence tests with the midge Chironomus riparius. Aquat. Toxicol. 65, 281-292.

Péry, A.R.R., Babut, M.P., Mons, R., Garric, J., 2006. Deriving effects on Chironomus population carrying capacity from standard toxicity tests. Environ. Toxicol. Chem. 25, 144-148.

Pieters, B.J., Liess, M., 2006. Population developmental stage determines the recovery potential of Daphnia magna populations after fenvalerate application. Environ. Sci. Technol. 40, 6157-6162.

Raimondo, S., McKenney, C.L., 2006. From organisms to populations: modeling aquatic toxicity data across two levels of biological organization. Environ. Toxicol. Chem. 25, 589-596.

Sibly, R.M., Williams, T.D., Jones, M.B., 2000. How environmental stress affects density dependence and carrying capacity in a marine copepod. J. Appl. Ecol. 37, 388-397.
Simas, T.C., Ribeiro, A.P., Ferreira, J.G., 2001. Shrimp-a dynamic model of heavy-metal uptake in aquatic macrofauna. Environ. Toxicol. Chem. 20, 2649-2656.

Tsai, J.W., 2005. Physiologically and bioenergetics based toxicokinetics and toxicodynamics and mode of action of arsenic toxicity to tilapia Oreochromis mossambicus. Ph.D. Dissertation, National Taiwan University.

Tsai, J.W., Liao, C.M., 2006. Mode of action and growth toxicity of arsenic to tilapia Oreochromis mossambicus can be determined bioenergetically. Arch. Environ. Contam. Toxicol. 50, 144-152.

West, G.B., Brown, J.H., 2004. Life's universal scaling laws. Phys. Today $57,36-42$.

West, G.B., Brown, J.H., Enquist, B.J., 2001. A general model for ontogenetic growth. Nature 413, 628-631. 